\title{
The Swedish Maintenance and Services Market in Wind Power Industry — Lessons Learned and Opportunities for Chinese Service Providers
}

\author{
Lihua Liu $^{12}$, Mike Danilovic ${ }^{13}$, Maya Hoveskog ${ }^{1}$, Fawzi Halila $^{1}$ \\ ${ }^{1}$ Centre of Innovation, Entrepreneurship and Learning Research (CIEL), Halmstad University, \\ Halmstad, Sweden \\ ${ }^{2}$ Shanghai Dianji University, Shanghai, China \\ ${ }^{3}$ Distinguished Overseas Professor at Shanghai Dianji University, Shanghai, China \\ The article received funding from Shanghai Dianji University Key construction Discipline: \\ International Economy and Trade Discipline, Project Number: 13XKJ02 \\ The authors have equal authorship
}

\begin{abstract}
This paper presents results from an investigation of maintenance and service market of Swedish wind power industry. Although the average number of disruptions per wind turbine only increased slightly from 2007 to 2009 in Sweden, the average downtime, the average electricity production loss and accordingly economic loss to the wind power operators increased 3 times during the same period. Equipped with strong production power, technology skills and expertize, Chinese wind turbine manufacturers have opportunity to enter the Swedish wind power maintenance and service market, and bring benefit to Swedish wind power industry and to themselves' internationalization process and sustainable development.
\end{abstract}

Key words: wind power, maintenance and service, Sweden, China

\section{Introduction}

Wind energy is kinetic energy of wind exploited for electricity generation in wind turbines. Since the end of the 1970 s oil crisis, a combination of policy drivers including reducing reliance on imported fossil fuels, improving energy security, encouraging new industrial development and addressing environmental concerns have driven global wind energy development (IEA, 2013). According to the Global Wind Energy Council 2012 market statistics, the global wind power market continued expansion in 2012, with annual market growth of almost $10 \%$, and cumulative capacity growth of about 19\% (GWEC, 2013). In 2012, there are 44,711MW newly installed and 282,482 MW cumulated wind power capacity around the world (GWEC, 2013).

However, the rapidly growing wind power industry is facing challenges now. Across Europe, wind industry is being hit by the economic crisis and austerity. Both the Chinese and Indian markets slowed somewhat in 2012.

According to Feng Zhao, an advisory consultant from BTM Consult company of Demark, which specializes in impartial and independent wind-industry research, facing the tough challenges, the 'new markets' opportunities exist in three fields, the first one is offshore wind power market, the second one is emerging wind power markets, the third one is maintenance and service market of wind turbine (Cui, 2012).

At the end of 2011, there are 199,064 wind turbines spinning around the world (GWEC, 2013). The ordinary warranty period of wind turbine is five years, while the life cycle of wind turbine lasts for 20 years. To keep good productivity along with an attractive rate of return of investment, the wind farm operators need to keep their wind turbines running without disturbances and to have a high availability. Thus, for the sustainable healthy development of wind power industry, high quality maintenance and service need to be offered to the wind turbines which have exceeded warranty period.

Feng Zhao from BTM reported that based on analysis of quarterly account statement of Vestas, the profit margin gained from their maintain service is much higher than their wind turbine production (Cui, 2012). The famous independent wind power consultant organization Wyman also forecast that, by the year $2020,40 \%$ of revenue and $60 \%$ of profit of wind turbine manufacturers will come from service they offer to wind power operators. The maintenance and service market of wind turbines is showing up a very attractive business field to wind turbine manufacturers now.

\subsection{The Swedish wind power industry faces \\ maintenance and service challenge}

Sweden is one country with the highest ratio of renewable energy to the country's whole energy supply, and the wind power industry in Sweden has grown extensively during the recent years. By the end of 2012, 
the cumulative installed wind power capacity in Sweden is $3,745 \mathrm{MW}$. However, a growing market also leads to new challenges. The emerging wind power industry starts to face the maintenance and service problem now.

The Swedish wind power market is dominated by two wind turbine manufacturers; Vestas and Enercon. In 2009 , Vestas controlled a $50 \%$ share of the market and Enercon came second with approximately one third of the market. With the strong dominant market position, the large wind turbine manufactures in the Nordic countries are spoiled (Hållén, 2008). Furthermore, there is information about a big wind turbine supplier in Sweden refused to provide maintain service to the old models of wind turbines they have sold to Swedish wind farm operators, in order to push the customer to buy their new model of wind turbines.

\subsection{Chinese wind turbine manufacturers crave for \\ new direction for further development}

The Chinese winder power industry has experienced impressive development in the recent years. The cumulative installed wind power capacity in China in 2012 has reached 75,564 MW (GWEC, 2013), a number that makes China the number one in this field in the world.

In line with the fast growth of wind power capacity, Chinese wind turbine manufactures increases apace as well. The competition among manufactures is intensified, and the price for the wind turbine has dropped from $6,500 \mathrm{RMB} / \mathrm{KW}$ in 2008 to 4000 $\mathrm{RMB} / \mathrm{KW}$ in the end of 2010. After the booming peak in 2010, the Chinese wind turbine manufacturers experienced the turning point of the market in 2011 and are suffering tough time now. Facing the industry winter and seeking long term sustainable development, Chinese wind power suppliers are craving for new development directions, internationalization is one important strategy they choose.

\section{Research Purpose and Methodology}

To investigate how maintenance and service of wind turbines are managed in Swedish wind power industry, how customers experience effects of disruptions and down-time and its economical consequences due to service \& maintenance solutions available, identify customers' satisfactory level of maintenance and service and to explore the possibility for Chinese wind turbine manufacturers to enter Swedish market, survey and interview were used to collect primary data (Duncker, Klötzer, Larsson, 2010). First step was survey among members (small onshore wind power operators) of two wind power association Svensk Vindenergi and Svensk Vindkraftförening by mail and email to explore the development of numbers of disruptions to the development of downtime, get data help us to estimate costs for maintenance and repair services of wind turbines and the economic impact from disruptions to the operators. Second step was interview of six large wind power operators in Swedish wind power market to obtain deeper qualitative data in order to achieve our research purpose.

\section{Data analysis}

\subsection{Wind power Maintenance and Service Market in Sweden}

\subsubsection{Bright Wind Power Market Future}

Sweden is the country with the highest proportion of renewable energy in the European Union, with $43.3 \%$ of total energy demand covered by renewable sources in 2007. However, the installed wind power capacity in Sweden is still very modest (GWEC, 2013).

According to the new EU Renewables Directive, Sweden must supply $49 \%$ of its final energy consumption from renewable sources by 2020 . In order to achieve this target, Sweden will be forced to increase its wind capacity to 20TWh and this requires a more rapid permitting process, the disappearance of the extensive appeals process as well as a new grid construction (The European Wind Energy Association, 2010).

\subsubsection{Attractive Green Certificate Support}

\section{System}

With the purpose to increase the production of renewable energy in a cost-effective way, the Swedish government introduced the so-called green certificate (elcertifikat) in 2003. The general objective is to raise renewable energy up to 25 TW in 2020 and at the same time to increase its competitiveness against other energy sources. The support system is a market based system that forces trade between renewable energy producers and other parties obligated to allocate by quota. These parties include electricity suppliers, electricity-intensive industry as well as end-users that produce their own electricity, import it or buy on the Nord Pool market place (Energimyndigheten, 2009).

For every MWh of renewable energy produced, the operator receives a certificate, which are then sold to electricity suppliers depending on how much electricity they sell. Through the sales of certificates the producers receive extra income which makes it more profitable to produce renewable energy (Energimyndigheten, 2010). Producers receive certificates for a maximum of 15 years for every new installed capacity, but only until 2030. The extra income from the certificate sales represents a substitute to former investment grants from the government (Energimyndigheten, 2010).

\subsection{The survey and interviewee respondents' profiles}

In total we received 43 valid survey results from 43 small onshore wind power operators. Most operators own less than five wind turbine and they have average active year of 6 years, which means they are comparatively new comers.

The interviewed wind power operators range in size, the lowest owning 8 wind turbines of a total of 
$15 \mathrm{MW}$ and the highest owning a total of 140 wind turbines adding up to $900 \mathrm{MW}$, they can all be considered as - large wind turbine operators, Three of six operators are quite new in the wind power market (Interviewees 4, 5, 6) and the other three are older companies in the industry.

\subsection{Disruptions, downtime, and costs}

Wind turbine is durable product that the useful life can last for 20 years. As large equipment with high unit value that operate in the harsh natural environment, facing the combined challenge of strong wind, rain drench and sand corrosion, wind turbine is liable to disruptions. Thus the maintain and service of wind turbine is critical to the efficient operation and satisfactory profit generation of wind farms, crucial to a lower cost of wind power offering to the society and a competitive advantage provided to wind power in relation to other energy sources.

The service and maintenance cost of wind turbines can take up 10 to 20 percent price of the wind power cost. All six interviewees confirmed service and maintenance to be their largest recurrent cost.

Failure in a wind turbine leads to direct costs for spare parts, maintenance equipment, transportation and maintenance staff required for correcting the failures, as well as to indirect costs due to production losses.

According to the investigation results, major disruptions often result from the break-downs of gearboxes, and most costly disruptions are the repairs and replacements of main components, such as blades, gearboxes and generators.

According to table 1, there is only slight increase in the number of disruptions per wind turbine over the years; however, the average downtime significant increased from 4.7 days in 2007, to 17 days in 2009, which the latter length is 3 times of the former one. Accordingly the average electricity production loss per turbine also tripled from 13.8 $\mathrm{MWh} /$ wind turbine in 2007 to $41.4 \mathrm{MWh} /$ wind turbine in 2009.

Table 1 Survey respondents' disruptions, downtime and costs

\begin{tabular}{|l|l|l|l|}
\hline & $\begin{array}{l}\text { Average } \\
\text { number of } \\
\text { disruptions }\end{array}$ & $\begin{array}{l}\text { Average } \\
\text { down } \\
\text { time }\end{array}$ & $\begin{array}{l}\text { Average electricity } \\
\text { production loss (MWh/ } \\
\text { wind turbine) }\end{array}$ \\
\hline 2007 & 2.35 & 4.7 days & 13.8 \\
\hline 2008 & 2.77 & 8.9 days & 21.1 \\
\hline 2009 & 2.72 & 17 ays & 41.4 \\
\hline
\end{tabular}

\subsection{Service and Maintenance}

\subsubsection{Choice of supplier for service and maintenance}

After the warranty expires, the operators have three possibilities: they can either sign a service agreement with the manufacturer or outsource maintenance to an independent service company or run the maintenance by themselves.

Among the survey responding operators, a majority of the reported wind turbines have no warranty left and majority of the operators choose to sign a fixed service agreement after the termination of the warranty. No matter operators with or without the fixed service agreement, manufacture is still the main source of the maintain service.

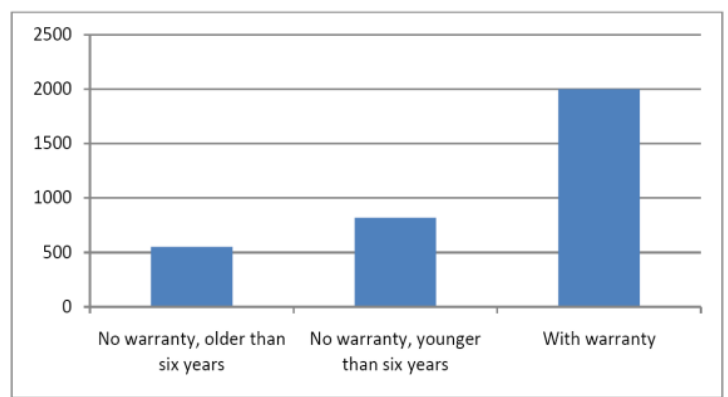

Figure 1 Average installed effect per wind turbine (KW) in terms of their age and warranty.

Investigation results (Figure 1) also shows that the wind turbines that still are under warranty have the highest average installed effect of $2000 \mathrm{~kW}$ (2MW). This not only means that compare to the wind turbines without warranty, the ones with warranty are much more productive, it also shows very clearly how seriously insufficient maintenance and service can affect the productivity of wind turbine.

\subsubsection{Satisfaction level with service and maintenance}

Regarding to survey responding operators, the average satisfaction level of the service supplier is about 3 on a scale from 1 to 5 . This figure demonstrates that the operators were not fully satisfied with their service supplier regarding service and maintenance as well as repairs.

Among five specific aspects of service and maintenance, cost in relation to quality, spare parts delivery time and lead times gain the lowest satisfactory.

Most interviewees were unsatisfied with the long lead times of the service personnel (Interviews 2 and 5). The interviewees explained the reasons for long lead time because of a shortage of personnel and spare parts.

\section{Discussion}

\subsection{Factors affecting downtime}

The length of downtime which is directly related to electricity production loss and thus indirect maintenance costs is influenced by different factors. We identified the following factors:

- Type of disruption

In the interview, the service company admitted that the length of downtime depends on the type of the disruption and varies greatly. Furthermore interviewees 4 and 5 acknowledged that disruptions due to minor electrical errors are often shorter than the repair or 
replacement of for example a gearbox or a generator.

- Efficiency and effectiveness of service and maintenance

If maintenance is performed efficiently (quick) and effectively (repairing the right part) downtime is reduced. This is because an efficient maintenance process requires less time than an inefficient maintenance process. Furthermore, an effective repair most often prevents future unnecessary downtime as this will prevent repeated break down of an ineffective repaired component.

- Response of the insurance contract

One of the interviewed company stated that long downtimes can occur because the operator might need to contact the insurance company and there can be problems if the insurance company is not willing to pay and/or if the insurance is willing to pay for the maintenance costs.

- Delivery time of right Spare parts

Another factor that influences the length of downtime is the shortage of a specific spare part according to the independent service company. Furthermore, in the last part of the survey the operators were asked to state their satisfaction level with different aspects of service and maintenance. The delivery time of spare parts was the aspect the operators were least satisfied with.

- Knowledge and experience

In the comments section of our survey several operators express their demand for more competent service personnel and complain about their wind turbine manufactures, who supply service and maintenance, to have too little experience and knowledge to supply effective and efficient service and maintenance. This demand shows us that the knowledge and experience of personnel is an influential factor on the length of downtime.

- Distance between wind turbine and service supplier

According to interviewee 1 the location of the wind turbine is essential. If the wind turbines are situated far from the service headquarters; it takes the service personnel longer time to get there which results in long downtimes. That geographic distance between the service supplier and the wind turbine is influential, as travel time increases for longer distances.

\subsection{The economic impact from disruptions to the operators}

Now we can calculate the economic impact an operator faces due to disruptions. Firstly we need to know what an operator earned per produced $\mathrm{MWh}$ in SEK for the years 2007-2009. These numbers are the average spot prices for wind power (Kundkraft, 2010).

2007: $0.280 \mathrm{SEK} / \mathrm{kWh} \gg 280 \mathrm{SEK} / \mathrm{MWh}$

2008: 0.491 SEK/kWh >> $491 \mathrm{SEK} / \mathrm{MWh}$

2009: $0.393 \mathrm{SEK} / \mathrm{kWh}$ >> $393 \mathrm{SEK} / \mathrm{MWh}$

Now we can calculate how much operators lost per wind turbine due to disruptions.

Average electricity production loss (MWh) $\mathrm{x}$ Electricity price $(\mathrm{SEK} / \mathrm{MWh})=$ Average electricity production loss (SEK)

2007: 13.8 MWh x 280 SEK = 3864 SEK

2008: 21.1 MWh x $491 \mathrm{SEK}=10360.1 \mathrm{SEK}$

2009: 41.4 MWh x 393 SEK = 16270.2 SEK

One has to remember that these are only indirect cost an operator faces due to disruptions, the total cost including material costs, component costs, personnel costs and overhead costs will be much higher than these numbers.

\subsection{Need for a more developed service and}

\section{maintenance market}

When analyzing the answers received from the survey we have several indicators that maintenance is not carried out properly. One indicator showing that maintenance is not working properly is that the average number of disruptions does not increase significantly from 2007 to 2009, but average downtime increases dramatically (table 1). Thus the increase of downtime should have other reasons than the increase in number of disruptions. We consider that inefficient service and maintenance is one big reason.

Several interviewees as well as several of the operators who commented in the survey experience that the service and maintenance market is inefficient. Two of the main reasons seem to be a shortage of competent personnel and a shortage of spare parts.

\section{Conclusions}

The conclusions of our research are: break-down of gearboxes is the most frequent disruptions wind turbines in Sweden are exposed to; the factors influence downtime are type of disruption, efficiency and effectiveness of service and maintenance, response of the insurance contract, delivery time of right spare parts, knowledge and experience, and distance between wind turbine and service supplier; the economic impact from disruptions to the operators is high and the satisfactory level of the wind power operators toward their present service and maintenance suppliers are not very high; the main challenges the wind power service and maintenance market facing are insufficient competent personnel and spare parts.

\section{Implications for Managers and Industry}

\subsection{Opportunity appears in the Swedish maintenance and services market in wind power industry}

Wind turbine operators of Sweden are today complaining of a general shortage of service and maintenance personnel (all interviewees). This demonstrates that there is a higher demand for service and maintenance than supply. With more and more wind turbines expiring from the warranty, the problem will be more and more obvious. This shortage is a sign of a growing service and maintenance market and a future market potential for new entrants. 
This point is confirmed by several interviewees who admit that in the future they expect more actors to enter the service and maintenance market and that there will probably even be specialized companies for the maintenance of different components of wind turbines.

Sweden has no domestic wind turbine manufacturer, even though there are assembly of Finnish WinWind WTG's and tower production for Enercon. The number of service and maintenance suppliers in the Swedish wind power market is small. It consists of the few wind turbine manufacturers and some independent service suppliers such as Triventus Energiteknik $\mathrm{AB}$ and ENGY Airtech AB. The interviews 2, 4 and 5 all confirm that there are too few service suppliers on the market and that more competition between the suppliers is needed.

\subsection{Challenges Chinese service providers facing to seize the opportunity}

As our research results disclose, the main challenges the wind power service and maintenance market facing are insufficient competent personnel and spare parts, and the lowest satisfactory elements among Swedish wind turbine operators are cost in relation to quality, spare parts delivery time and lead times. In order to grasp the Swedish market opportunity, Chinese service providers must capable of solving these problems.

Chinese second largest wind turbine manufacture Gold Wind Company has started its transfer from an equipment producer to a one-stop solution provider. Gold wind has established a subsidy company, Tian Yuan New Energy to focus on the service market of wind power industry in 2005. Tian Yuan is a one-stop solution provider with service covering the whole life cycle of wind power projects. The company's delivery of technical services to wind farms in China for the past seven years has facilitated Tian Yuan's progress into new areas of wind power development, including early stage services such as site selection, wind measurement consultation, intermediate stage services such as general project contraction, project administration, and late stage services such as EPC, commissioning, wind farm operation and maintenance, spare parts management. Gang Wu, Gold Wind Company's president forecast that the service business of the company will increase at a speed of $50 \%$ each year and revenue gained from service business will become more and more important.

Chinese biggest wind turbine manufacturer Sinovel's two SL3000 3MW turbines have come into service in a wind farm $35 \mathrm{~km}$ northeast of Karlstad in central Sweden on 29 February 2012. It marked the first time that China-made wind turbine entering the Swedish and European market.

Chinese wind turbine producers' journey to Sweden has started; however, to satisfy the maintenance and service market of Swedish wind power market is still full of challenges.

\subsubsection{Provide competent personnel capable of working in international context}

Firstly, a wind turbine is a highly technical device and therefore the service and maintenance requires knowledge and experience about the function of a wind turbine. The Chinese maintenance and service suppliers need to match their wind power service team to the European wind turbine, which means either make their Chinese employees get familiar with wind turbines used in Swedish market, accumulate experience of maintaining these European wind turbines or hire employees from local market. Considering of the high cost of human resource in Europe market, and the lacking of hand in local market already, it's more practical for the Chinese companies choose to train their own maintenance and service teams that are capable of working under international circumstance.

This requires Chinese service providers to give their service personnel enough training of knowledge of wind turbines that are common in European and Swedish market, as well as English language skills that ascertain them to communicate efficiently to local customers.

\subsubsection{Provide spare parts in a time efficient manner}

In order to run a service and maintenance business a new entrant will also have to take into account the need of spare parts, which can be costly and hard to get hold of. One operator comment in the survey expressed this issue with the following words:

"Alternative service suppliers are very important for

the development of the industry. These alternative suppliers have to get access to the manufacturers' spare parts and knowledge."

Spare parts and maintain and service equipment delivery time are one of the key element to shorten the downtime and raise the satisfactory of customer. Wind turbines are complex equipment consist of huge amount of components, which some of the parts are very big that are difficult and not economical to transport for long distance. How to provide maintain and service equipment, how to manage the inventory and delivery of demanded spare parts to the local wind power operators? These are all questions Chinese suppliers need to find answers.

\subsection{Strategy suggestions to Chinese suppliers}

\subsubsection{Joint education and training of personnel tailored to Swedish and European wind power industry}

European countries, especially Demark, Spain, German, and Sweden are leading countries in new energy field and wind power industry in the world. Chinese companies could deploy various joint education and training programs including class room teaching, case study, company visit, joint research project, wind farm practice and internship together with European universities and wind power industry, provide 
Chinese trainees with advanced knowledge and technology in wind power industry in Europe, sufficient English communication skills, and opportunity to accumulate working experience in European and Sweden context.

In August 2013, 27 master students majored in Electric Engineering (focused on wind power industry) from Shanghai Dianji University, China are spending three months at Halmstad University for a special 15 $\mathrm{hp} /$ ECTS program in Wind power innovation. In the cooperative program, the Chinese students are arranged to take course in wind power technology by Swedish experts who has more than 30 years of working experience in Swedish wind power industry, introduced to the advanced professional software in wind power industry, given opportunities to visit the construction site of a Swedish wind farm, visit leading wind turbine companies like Vestas and given vivid lectures about Swedish culture. This is a very good example of joint education program to solve the personnel challenge. It is very possible that the Chinese students involved in the collaborative program will be much better prepared to serve the Swedish maintenance and service market of wind power industry after they finish the study and it is foreseeable that in a few years, their working experience in Swedish wind power market will be a valuable asset they can expand to the world market which ultimately become a strong competition edge of Chinese wind power companies.

On the other hand, Chinese employees' hard working attitude, easy going personality, quicker response and more flexible working schedule are advantages that could make Chinese maintenance and service suppliers more attractive and more satisfactory to Swedish wind power operators. For instance, Sinovel has sent 8 maintenance and service employees stay long term at the workplace that is only 600 meters from where their two wind turbines were installed in Sweden. "Western wind turbine suppliers don't usually keep service staff stay at wind farms, however, Sinovel's engineers will stay at the Swedish wind farm and provide quick response service for the following 10 years", Vice president of Sinovel Lecheng Li said (Liu, 2012).

\subsubsection{Collaboration with Swedish parts suppliers}

Swedish companies are strong in component industry, there are several Swedish companies such as $\mathrm{ABB}$ and SKF which produce and export a variety of components, like main shafts, generators, towers and bearings, to wind turbine manufacturers in Denmark, Germany and other countries. It is possible for Chinese companies to form strategic alliance with local component producers. Or Chinese service suppliers could consider to produce locally by themselves as well, or combine transport parts from China and locally out sourcing. Chinese Gold Wind has done a good job in localization in its international market. The company purchased blades and tower barrels in US when they construct their wind turbines in the US market, and transported other parts and components from China.

In general, Swedish maintenance and service market is a market with great potential for Chinese wind power companies. This is a new segment of market for the Chinese players. To seize the business opportunity, Chinese wind need deploy creative business model innovation to combine the resource they possess in a new way, design tailored process that might not exist before to the Swedish maintenance and service market, and even adopt now philosophy of gaining profit to serve this market. If Chinese companies succeed in seizing the opportunity, not only Chinese wind power companies will gain benefit, the Swedish wind operators will work more efficiently and economically, but also the world green energy production will improve a great deal.

\section{References}

[1] Alyouf, I., "Cost Effective Maintenance for Competitive Advantages". Växjö, Växjö University Press, 2004.

[2] Elforsk AB., "Driftssikkerhet for vindturbiner" (Elforsk rapport 09:21) Report. Stockholm: Elforsk AB, 2009.

[3] Energimyndigheten. Vindkraftsstatistik. Available at <http://www.energimyndigheten.se/Global/Press/Press meddelanden/Vindkraftsstatistik\%202009.pdf >.

[4] GWEC, "Wind in Numbers". Available at $<$ http://www.gwec.net/global-figures/wind-in-numbers/ $>$.

[5] Hållén, J., "Stopp för vindkraftverk hos försäkringsbolagen". Ny Teknik. Available at <http://www.nyteknik.se/nyheter/energi_miljo/vindkraft /article400835.ece>.

[6] Hanqing Z, "Development Strategy of Chinese Wind Power Industry Based on Global Perspective", Journal of Changchun Institute of Technology (Social Science Edition), Vo.1 11, No. 3, pp. 39-43, 2010.

[7] Honewei C., "Wind Turbine Producers' New Market Opportunity Exist in Four Fields". Electric Power System Equipment [online], Available at: < http://www.meb.com.cn/news/2012_12/18/1634.shtml >

[8] IEA, "Topic: wind power". Available at: $<$ http://www.iea.org/topics/windpower/>.

[9] Kundkraft, "Spotpriser". Available at $<$ http://www.kundkraft.se/?fto=content/prices\&name $=$ p rices_spothttp://www.nyteknik.se/nyheter/energi_miljo/ vindkraft/article723131.ece>.

[10] Zhonghua L., "Chinese Wind Turbine Blowing Whirlwind in Sweden", People's Daily, pp. 5, March 9th , 2012.

[10] Duncker, N., Klötzer, A., Larsson, K., "Gone with the Wind, The economic impact of disruptions, A study of service and maintenance in the Swedish wind power market”. BA. Jönköping Universiy, Sweden, 2010. 